\title{
Exporting Barriers Perceived by Manufacturing SMEs: Evidence from Emerging and Advanced Markets
}

\author{
Dr. Yousif Abdullah Alrashidi \\ College of Business Administration, Al Yamamah University, P.O. Box 12276, 11473 Riyadh, Saudi Arabia
}

\begin{abstract}
This paper explores the exporting barriers perceived by the Saudi Arabian and Australian Small and MediumSized (SME) businesses considering (or engaged in) exporting within manufacturing. Currently there is a paucity of research comparing and examining exporting barriers and obstacles facing exporting Saudi Arabian and Australian SMEs within manufacturing settings. Moreover, this is one of the first examination of these barriers within these contexts (Saudi Arabia and Australia). A total of 35 interviews (21 interviews from Saudi Arabia and 14 Australian) with SMEs mangers/owners within manufacturing industries were completed. The results suggest that SMEs managers' perceived a total of 19 exporting barriers, influence their exporting decision and commitment. We recommend the use of a large scale survey to clarify the appropriateness of the barriers identified in this study so as to arrive at more generalisable results.
\end{abstract}

Keywords: exporting barriers, exporting SMEs, perceived risk, Saudi Arabia, Australia manufacturing.

DOI: $10.7176 / \mathrm{EJBM} / 11-12-17$

Publication date: April $30^{\text {th }} 2019$

\section{Introduction}

International trade is an important contributor to a nation's economic growth and sustainability (Al-Aali, 1995; Asiedu \& Lien, 2004). Currently, exporting represents one of the most common international trade activities and modes of entry into international markets. Although multinational-enterprises (MNEs) have tended to dominate global trading activities, over the past three decades, small and medium-sized enterprises (SMEs) have played an increasingly important role in global trade. Currently, SMEs contribute between 25 to 35 per cent of world manufacturing exports. While a wide body of literature exists on the export practices of firms, the majority of studies have conducted in advanced markets (Crick et al., 1998), and mainly focused on the large-scale firms. This provides an important gap within the existing literature to be addressed concerning the need for more studies to be conducted in both emerging and advanced markets to compare how SMEs operating within different economic level courtiers differ in perceiving exporting barriers, which have received limited attention. To date, minimal research has investigated the barriers and obstacles facing Saudi Arabian and Australian SMEs exporters within manufacturing. This omission represents a significant gap in the literature, and forms the basis for the current study.

\section{Literature Review}

Arguably, one of the most widely investigated areas in the exporting literature pertains to the barriers to exporting (Barkema et al., 1996). These obstacles or barriers include those problems and constraints that are faced, or hold back, a firm's ability to start, develop, or continue business activities in foreign markets (Leonidou, 2004; Abonyi, 2015). In addition, many studies have identified the factors hindering firms from initiating, developing or sustaining exporting activities (Leonidou, 1995a). Exporting barriers have been grouped into two categories: internal and external. Leonidou (2004) suggests that internal barriers are those associated with an exporting organisation's resources, capabilities and approaches to exporting (i.e. information, functional and marketing barriers). In contrast, external barriers are those stemming from both home and host country environments, such as foreign rules, regulations, tariff barriers and differing societal customs. Further, previous research has identified additional obstacles, including psychological, operational, organisational, and product/market elements (Hamill, 1997).

Other studies have identified several broader external and internal barriers, including: external, operational, internal, and informational problems (e.g. Katsikeas \& Morgan, 1994). However, studies by Kaleka and Katsikeas (1995), Morgan (1997), and Leonidou (1995b) have extended these areas and re-termed them as: internal-domestic export barriers; internal-foreign export barriers; external-domestic export barriers; and external-foreign export barriers.

\subsection{Export barriers and Firm Characteristics}

A range of factors have been identified as influencing and shaping a firm's export behaviour(Katsikeas \& Morgan, 1994; Clercq \& Zhou, 2014). Indeed, such behaviour is heavily influenced by management's perception of the barriers associated with exporting activities; this perception is influenced by the firm's characteristics, such as firm size and export experience (Samiee \& Walters, 1990). The findings of several empirical studies have shown that 
the size of the firm is a key determinant of its' export propensity (Burton, 1987; Reid, 1981). Therefore, smaller firms, without size advantages, will be impacted upon (negatively) in terms of their export activities (Katsikeas \& Morgan, 1994). Advantages connected to a firm's size include the number of staff, financial resources, and capabilities. Hence, firms with higher capabilities and resources are able to direct greater efforts towards exporting success than firms with limited resources and capabilities (Cavusgil \& Naor, 1987; Reid, 1981). However, research by Aaby and Slater (1989) has shown that there is little agreement over whether the firm's size has an impact on its exporting activities performance and behaviour.

Nevertheless, there is consensus that a firm possessing more resources and capabilities usually achieves higher levels of economies of scale and, thus, have lower levels of perceived risk associated with their exporting activities (Bonaccorsi, 1992). In support of this view, Katsikeas and Morgan (1994) posit that there are significant differences between a firm's size when dealing with exporting barriers, namely, information/communication with the export market, product adaptation, and exogenous logistical constraints. As a consequence, smaller firms perceive more problems than did larger firms.

Thus, exporting barriers provides a point of investigation in relation to international marketing activities. However, little is known of what are the barriers and obstacles perceived by Saudi Arabian exporters SMEs within manufacturing and how they differ than their counterparts in Australia. Unfortunately, to date, minimal work has been undertaken in relation to comparing barriers and obstacles facing exporters SMEs within manufacturing operating within emerging and advanced markets. It is on this basis that one broad research question is posed in this study:

RQ: What are the perceived barriers (to export) of export-decision makers and how do these differ across advanced versus emerging markets?

\subsection{Objectives / Proposed Conceptual Framework}

The importance of the contribution of exporting SMEs within manufacturing to both counties economy and job creation is clear from the literature review. The SMEs growth is one of the most important factors that to keep such firms developing and exporting is considered one of the most important forms of such growth. Hence, to sustain and maintain such growth SMEs need to overcome export barriers. After a through examination of the literature review that have led to the following research objective:

(1) To investigate the perceived barriers (to export) of export-decision makers and how do these differ across SMEs operating in emerging and advanced markets; and

(2) To examine the influence of the perceived barriers to export on the SMEs exporting behavior.

The conceptual framework of this study is presented in this section, along with the development of research propositions. The framework is comprised of four main factors:

(1) Internal-Domestic Export Barriers;

(2) Internal-Foreign Export Barriers;

(3) External-Domestic Export Barriers; and

(4) External-Foreign Export Barriers (see Figure 1).

Figure 1: The conceptual framework of this research

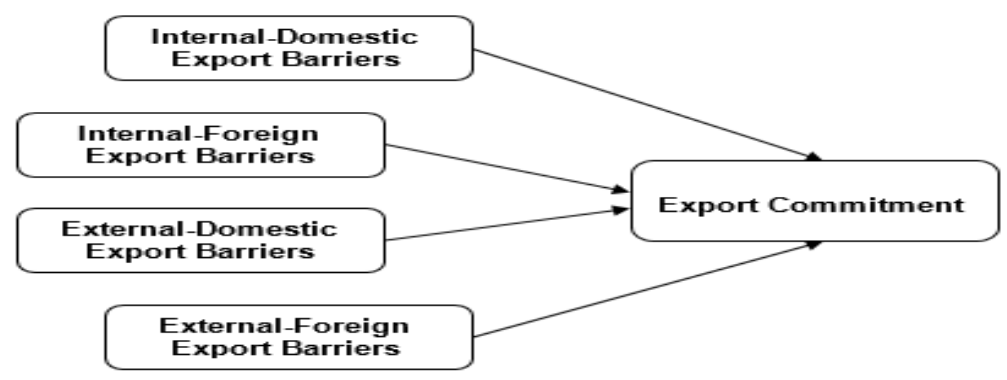

\subsection{Propositions Development}

Exporting is considered (in both developed and developing countries) as an important tool to survive and succeed in the global environment, even though it may involve many difficulties and constraints for firms engaged in, or planning to, export (Al-Aali, 1995). Firms that are exporting from developing countries face obstacles that differ from their counterparts in developed country contexts (Ford et al., 1987). Obstacles or barriers to exporting include problems and constraints that face and hold back a firm's ability to start, develop, or continue business activities in foreign markets (Leonidou, 2004).However, to date, the majority of research, conducted in the field of exporting barriers, has focused on developed markets (Al-Aali, 1995). 


\subsection{Exporting Barriers in Developed and Developing Markets}

In developed markets research has highlighted several obstacles faced by exporters. First, there is the risk of doing business overseas (commercial and political risks) (Bauerschmidt et al., 1985; Lim et al., 1991; Sullivan \& Bauerschmidt, 1990; Al-Hyari, Al-Weshah, \& Alnsour, 2012; Abonyi, 2015), as well as the firm's inability to reach foreign market demand, especially for small-scale manufacturers (Moini, 1998; Rabino, 1980). Second, the cost of doing business overseas can prove too expensive, especially in relation to the cost of raw materials, and the high tariffs on imported products in those foreign markets (Bauerschmidt et al., 1985; Sullivan \& Bauerschmidt, 1990). Third, the lack of government assistance or actual export related hindrances also creates problems (Bauerschmidt et al., 1985; Lim et al., 1991; Sullivan \& Bauerschmidt, 1990; Al-Hyari et al., 2012; Jamshed, Arslan, \& Umair, 2011; Abonyi, 2015). The fourth barrier to exporting relates to the lack of knowledge about overseas opportunities (Lim et al., 1991; Moini, 1998; Jamshed et al., 2011; Al-Hyari et al., 2012; Pinho \& Martins, 2010; Organisation for Economic Co-operation and Development, 2009). Fifth, there is the high level of competition in the foreign markets (Bauerschmidt et al., 1985; Sullivan \& Bauerschmidt, 1990; Al-Hyari et al., 2012). Furthermore, problems associated with international marketing, such as the lack of foreign distribution knowledge, also create barriers (Bauerschmidt et al., 1985; Sullivan and Bauerschmidt, 1989; Kaynak, 1992; Kaynak \& Kothari, 1984; Kedia \& Chhokar, 1986; OECD, 2009; Abonyi, 2015). In addition, the existence of product usage (Bauerschmidt et al., 1985; Sullivan \&Bauerschmidt, 1989), safety and quality standards can differ and cause exporting problems (Bilkey, 1978; Rabino, 1980; Tookey, 1964; Jamshed et al., 2011; Al-Hyari et al., 2012).

Moreover, the financial obstacles associated with collecting money in foreign markets revolve around the high value of the home currency (Bauerschmidt et al., 1985; Sullivan \& Bauerschmidt, 1989; Moini, 1992; Abonyi, 2015), exchange currency fluctuations (Kaynak, 1992), credit problems, insurance problems, and, more generally, the collection of money (Kaynak et al., 1987). Furthermore, complexities in export and import regulations and procedures (in both the home and host countries) create difficulties (Bauerschmidt et al., 1985; Pavord \& Bogart, 1975; Rabino, 1980; Sullivan \& Bauerschmidt, 1990; Yaprak, 1985).

Another barrier, identified in the international marketing literature, centres on the lack of language and cultural knowledge, or differences in backgrounds which can result in misunderstandings and conflict (Bauerschmidt et al., 1985; Pavord \& Bogart, 1975; Rabino, 1980; Sullivan \& Bauerschmidt, 1990; Yaprak, 1985). A further barrier is created due to the lack of strategic resources, such as: productive capacity (Bauerschmidt et al., 1985; Sullivan \& Bauerschmidt, 1990; Yaprak, 1985); qualified staff (Dichtl et al., 1990; Rabino, 1980; Yaprak, 1985); and management time. Furthermore, there are a host of(miscellaneous) obstacles, which include general exporting difficulties (Kedia \& Chhokar, 1986; Weinrauch \& Rao, 1974), as well as trade restrictions imposed by governments (Kaynak \& Kothari, 1984; Moini, 1998; Rabino, 1980; Jamshed et al., 2011; Al-Hyari et al., 2012).

On the other hand, some researchers have extended the work conducted in the context of advanced markets and deployed such knowledge into developing market areas in an attempt to explore the obstacles and barriers facing and hindering firms' opererationalising in such environments. For example, Christensen, Rocha and Gertner (1987) suggest other potential barriers that may face Brazilian (i.e. under developed economy) exporters. Their study identified four obstacles: inadequate financial incentives; strong international competition; resources and capabilities of the firm; and the focus on the domestic market demand. Also of interest is a study by Tseng and Yu (1991) of Taiwanese firms exporting goods into European markets. They found that the most important barriers and constraints were a lack of foreign market information, limited trading knowledge of personnel, and the inappropriateness of the quality of exchanged goods for the needs of the new market (Leonidou, 1995a).

In another study, Crick et al. (1998) found that the most important obstacles faced the Saudi Arabian manufactures included: competition in export markets; a lack of market information, fear of imposed dumping policies; increasing tariffs, unclear trade agreements, import restrictions, the cost of importing raw materials, and the lack of suitable personnel. Consequently, these barriers influence and shape a firm's export behaviour (Katsikeas \& Morgan, 1994). Concurrently, a firm's export behaviour is heavily influenced by the management's perception of the export barriers associated with such activities. Additionally, firms from emerging markets are facing different barriers than their counterparts from advanced markets.

\subsection{Barriers Classifications}

Following the previous review of the exporting barriers literature, the classifications of exporting barriers are discussed. From the literature review, early research classified barriers to exporting into two categories: internal and external. However, later studies by Kaleka and Katsikeas (1995), Morgan (1997), and Leonidou (1995b) have extended the areas to include: internal-domestic export barriers; internal-foreign export barriers; external-domestic export barriers; and external-foreign export barriers.

\subsubsection{Internal-Domestic Export Barriers}

The internal-domestic export barriers include problems and factors that a firm experiences within in their home 
country (Crick et al., 1998). These include a lack of qualified staff for international activities (Pavord \& Bogart, 1975; Vosikis \& Palmour, 1980; Yang, Leone, \& Alden, 1992; Pinho \& Martins, 2010; OECD, 2009); poor organisation and formalisation of export departments (Bauerschmidt, Sullivan, \& Gillespie, 1985); insufficient production capabilities (Alexandrides, 1971; Yaprak, 1985); lack of managerial time (Kaynak \& Kothari, 1984); and the firm's concerns regarding developing domestic market activities (Keng\& Jiuan, 1989). These barriers are often related to the firm's management experience and capabilities, which can vary from country to country. Further, the barriers may also relate to the economic development of each country. That is, countries from emerging markets may differ from their counterparts in advanced countries. Indeed, those differences may also influence their decision to export and, consequently, even influence the way they behave, when undertaking international activities. Based on the above arguments, the following proposition is presented:

P1: Internal-domestic export barriers will influence the decision to export and these barriers will differ across exporters operating within advanced versus emerging markets.

\subsubsection{Internal-Foreign Export Barriers}

Second, internal-foreign export barriers (such as problems experienced in the host country and the firm's adjustment to such problems) include high transportation costs (Bauerschmidt et al., 1985; OECD, 2009); low product quality (Gripsrud, 1990, Jamshed et al., 2011); transportation and shipment difficulties (Cheong \& Chong, 1988; Kedia \& Chhokar, 1986; Kaynak\& Kothari, 1984; OECD, 2009); limited knowledge of market intelligence to research foreign markets (Barker \& Kaynak, 1992; Barrett \& Wilkinson, 1985; Bilkey \& Tesar, 1977; Hook \& Czinkota, 1988; Yaprak, 1985; Pinho \& Martins, 2010; OECD, 2009; Al-Hyari et al., 2012; Abonyi, 2015); and risks and costs in selling abroad (Tesar \& Tarleton, 1982). Barriers within this category are mainly related to the country's infrastructure in the home and host markets, as well as the firm's product quality, and the availability of information pertaining to overseas markets.

Such barriers may are not exist in some markets, or all of them may be experienced by some firms. The outcome depends on the countries in which the firms are operating from, and may be influenced by the targeted markets. For example, a recent study found that firms, from emerging markets, experience barriers related to product quality, while advanced market firms face transportation problems when they target developing markets (Nuopert et al, 2006). Hence, it is posited that:

P2: Internal-foreign export barriers will influence the decision to export and these barriers will differ across exporters operating within advanced versus emerging markets.

\subsubsection{External-Domestic Export Barriers}

Third, external-domestic export barriers arise from the external environment, (but are still experienced by the firm in their home country)include the complexity of the paper work involved in exporting (Tesar\& Tarleton, 1982; Barret\& Wilkinson, 1985; Cheong \& Chong, 1988; Keng \& Jiuan, 1898; Abonyi, 2015); the high cost of capital to finance exports (Brooks \& Rosson, 1982; Hook \& Czinkota, 1988; Korth, 1991; Vosikis \& Palmour, 1980); the lack of government assistance to overcome export barriers (Yaprak, 1985; Pinho \& Martins, 2010); the lack of attractive export incentives; and inadequate promotion of the programs provided by the government (Albaum, 1983; Pinho \& Martins, 2010; Abonyi, 2015). These difficulties differ from country to country, mostly because government support varies considerably within each country. However, the availability and access to funds also differs from one country to another, most often linked to the economic level of the development of the country. Thus, it is proposed that:

P3: External-domestic export barriers will influence the decision to export and these barriers will differ across exporters operating within advanced versus emerging markets.

\subsubsection{External-Foreign Export Barriers}

Fourth, external-foreign export barriers arise from the external environment and are experienced by the firm in the host country; examples include: restrictions imposed by foreign government rules and regulations (Hook \& Czinkota, 1988; Jamshed et al., 2011); a lack of information about overseas markets (Kedia \& Chhokar, 1986; OECD, 2009; Pinho \& Martins, 2010; Al-Hyari et al., 2012); difficulty in making foreign contacts, including intermediaries (Samiee \& Walters, 1990); a lack of export market distribution channel structures and development (Dichtl, Koeglmayr, \& Mueller, 1990; Kaynak \& Kothari, 1984; Lim et al., 1991; OECD, 2009; Abonyi, 2015); intensity of competition in export markets (Dichtl et al., 1990); language and cultural differences (Gripsrud, 1990); and the high value of the domestic currency (Yang et al., 1992). However, firms also differ in how they perceive these obstacles and barriers and these perceptions are often influenced by their level of involvement in exporting activities (Morgan, 1997), which are based on the country-specific situation of their home country and their host (or target) country. Hence, the following proposition is presented:

P4: External-foreign export barriers will influence the decision to export and these barriers will differ across exporters operating within advanced versus emerging markets.

\section{Methodology \\ 3.1 Sample}


The present research was conducted on 35 SMEs from diversified fields located in Saudi Arabia and Australia and involved in Exporting using purposive random sampling technique. Certain demographic characteristics were also taken into consideration.

\subsection{Tools Used}

Unstructured set of questionnaire using convergent interview style has been developed and the responses of the subjects were kept open ended. The questions were developed keeping in mind the objective of the study.

\subsection{Procedure}

The interview sessions were conducted via the telephone, and the participants were asked open-ended questions regarding their exporting experience, management styles and risk perceptions (associated with exporting). All interviews were audio-taped (with the participants consent) to ensure accuracy in transcription and data analysis. Following each interview the researcher listened to the recordings and transcribed the interviews verbatim. Summary notes of the participants' characteristics, enthusiasm, and overall tone and mood during the interview were also recorded. The researcher analysed each transcription prior to any subsequent interviews. This method facilitated the capture of salient themes that were measured with each subsequent interviewee, to identify whether they converged or diverged with the original themes (Dick, 1990). Consequently, the follow-up questions narrowed the focus as different themes and perceptual frameworks were seen to emerge. The interviews were conducted until all patterns of convergence were felt to be satisfied and any major diversions were explained. Last, this research is an exploratory in nature (evidenced by the small sample size), therefore, the findings cannot be generalised to the larger population.

All the care has been taken to minimize the Interviewer Biasness while conducting the interview and interpreting the content of the interview.

\section{Findings}

The findings of this study are presented in this section, and these findings are presented in sequential manner starting with Saudi Arabian interviews results followed by the Australian results.

\subsection{Saudi Arabian Interviews}

During the course of the interviews, the influence of the exporting barriers on SMEs decision-makers' risk perception and their export behaviour were revealed. The participants were prompted to discuss any issues surrounding barriers/impediments to exporting. The results show that the more external barriers, in both home and host countries, that were faced by the firm, played a strong role in influencing the decisions of the Saudi SMEs managers to export. Four types of barriers were nominated by participants. The barriers were (later) classified (according to the framework provided in the literature review) into four groups: internal-home, internal-foreign, external-home and external-foreign. The results suggest that these different categories of exporting barriers influence the final export decisions.

\subsubsection{Internal-Home Barriers}

Internal home barriers were mainly associated, with a manager's qualifications and knowledge of exporting. The results show that these internal-home barriers influenced Saudi SMEs decision-makers' export-related decisions in one way or another, and that these influence vary, depending on how those managers perceived such barriers. Most of the participants (with the exception of E1 and J1) agreed that the two most important barriers were, and continue to be, the lack of qualified staff for the management international market operations and, also, the lack of internationally experienced SMEs managers. Their situation was exacerbated due to the relatively small size of their businesses, with limited experience and money. Therefore, they were unable to hire more experienced employees. However, two participants reported that they had not confronted either of the barriers because they were very experienced, and had good resources (both financial and human resources). For example, participant N1 confirmed that: 'The lack of international experience by the managers, and the lack of qualified staff, in these activities make it difficult to export when there are problems, especially when it comes to entering new markets'. Similarly, another participant (H1) agreed on that: 'I have been dealing with exporting for just three years and from this I can tell that I don't have the proper and needed experience to enable us to be active exporters, looking for new markets overseas'.

Another barrier faced by a majority of participants (B1, C1, G1, H1, I1, K1, L1, M1, N1 and O1) was their limited knowledge of market intelligence, which was reflected in their lower capacity to research foreign markets prior to entry. According to participant K1 this was: 'Because of our short experience in exporting, we have never been good at doing market research of foreign markets. Additionally, we have not been able to find any proper or reliable formal or informal channels to provide the needed information for such market research'. The problem of a lack of information was also supported by participant I1: 'Because most of the time I have no clear and accurate information about the markets, especially foreign ones, I don't export to most of the markets to avoid the 
financial risk (not getting paid by overseas customers) that I would have if I exported to such markets'.

\subsubsection{Internal-Foreign Barriers}

Overall, the results of the in-depth interviews suggest that a strong majority of participants have never experienced any internal-foreign barriers; however, participants B1, F1 and I1 identified, and faced, one internal barrier in the foreign markets, namely, the low quality of their products. As a consequence, they were cognisant that they could not compete on quality in overseas markets, so they do not actively export. Additionally, they also feared the loss of their reputation; and that' is why they do not export until they received overseas orders from customers looking for competitive products (based predominantly on price). Thus, participant I1 stated that 'We do not export actively because of the low quality of our products. This is the main reason that why we don't export until we receive an order from a potential overseas customer looking for cheap products, regardless of the quality'. Additionally, another participant (F1) confirmed that: 'Our equipment is not up-to-date and that's why we can't compete on quality in most of the regional markets. The Gulf markets have alot of opportunities, but because of our low quality products we are not actively exporting, unless we receive an order. In other words, we never chase customers'.

\subsubsection{External-Home Barriers}

The interviews also showed that many barriers are related to the company's external environment of the home market and that, in some way, influences their exporting decisions, and how they behave (either positively or negatively). Such barriers include the lack of real or sufficient financial support, from the government, for SMEs to export (identified by a majority of the participants, except H1 and K1). Moreover, a strong majority of participants agreed that, when expanding their business, the lack of government funding had them worried; hence, they were extremely careful when exporting to different markets, especially in terms of increasing production, and investing in the purchase of new equipment. Both issues required additional funding and involved significant timelags, which often impacted on the resultant (anticipated) competitive positioning in the host country. For instance, participant G1 stated that: 'For me I can't cover a lot of markets because of the production capacity, and if we want to export to more markets we need to make modifications to our production lines and that needs money which we don't have, and the government do nothing to assist us with the lack of funds'. Another participant (A1) was in agreement with the above statement: 'Saudi SMEs need real government support during the start-up stages to assist us to buy up-to-date machinery to enable us to compete in the very competitive international markets'.

In addition, a majority of participants faced difficulties in handling the documentation related to exporting. All agreed the paper work was too complex and to costly, which some suggested may prohibit some SMEs from engaging in exporting. For example, participant L1 stated that: 'The cost of handling and verifying the exporting documentation (for example, issuing and verifying the certificate of origin) is around 25,000 US\$ annually, which is then added to the price of our product; this would have a negative effect on us if the price was higher than that of our regular competitors'.

In addition, all participants reported that a lack of government assistance to overcome export problems posed a major barrier that was often difficult to overcome, and, again would certainly prohibit some SMEs from engaging in exporting. As participant K1 said, that for: 'SMEs managers, to be successful and active exporters, need to attend a lot of training workshops to show them how to grow their business and expand it internationally. Moreover, exporting SMEs need governments to sponsor these workshops and the marketing of SME products through international exposure, and through the overseas government commercial attaches.'

Further, a majority, (seven in all; C1, D1, G1, H1, L1, M1, N1 and O1) found that the high cost of importing raw materials, and the fluctuation in their prices, a major deterrent to actively export due to the concomitant price flow-on effect for their products. This situation is reflected in participant N1's statement that: 'The expensive imported raw materials forced us to increase our price; that impacted on us badly because our foreign competitors were keeping their old price, which harmed us badly'. Similarly, participant O1 stated that: 'The high cost of importing raw materials, and the fluctuation in their prices, was one the major deterrents to being active exporters. The increase in the prices of the raw materials that we depend on to produce our final products effects our final prices, and that deters us from competing in some of the markets with cheaper products'.

\subsubsection{External-Foreign Barriers}

From the convergent in-depth interviews, there also appears to be few problems related to external-foreign barriers. Most participants favoured exporting to countries with similar cultures and languages, and with markets in close proximity. A number of companies did export to the African and European markets, and they did experience, to some degree, a range of barriers that negatively influenced their risk perceptions and their final decisions to export. Specifically, one barrier centered on changing tax and monetary policies, as reported by participants E1, J1 and L1, because they exported to regions outside the Arabian Gulf area. However, most interviewees suggested that in the Arabian Gulf region taxation and monetary policies have never been an issue. Another barrier related to other countries' internal security. A strong majority of participants (B1, D1, E1, F1, I1, J1, K1, L1, M1, N1 and O1) identified this problem as a focal issue, which could prevent companies from exporting to a specific country. For example, the participant B1 commented that: 'Lebanon is a promising market and is full of opportunities and the customers have never stopped asking for our products. However, I don't export to them because after the war in 
2006 the country remained unstable; the conflicts between different local parties forced us to stop dealing with any Lebanese order because we were afraid of not getting paid'. Furthermore, according to participant N1, internal security can be a real barrier, such as: 'What happened in Bahrain during February 2011 negatively affected our trading with our partners because, after the demonstrations, everything in the country became paralyzed'.

Significantly, a majority of participants, to a greater or lesser extent reported exporting problems with changes to the legal regulations in other countries; that is, those regulations, which attempted to protect the foreign county's local products, and consequently impacted on the exporters' products. As participant O1 complained: 'One of the countries that we export to had changed their standards and their accepted quality of our industry products. Hence, any product that did not meet the new standards was banned. For this reason, we stopped exporting to that market because, to increase our quality, we would have had to increase our prices, and the two local manufacturers (owned by the government) would continue to sell the same product cheaper by $20 \%$ '.

Only three participants (E1, J1 and L1), who exported to non-Arab markets, found that the tariffs on imported goods constituted a big barrier. Any increase in tariffs had to then be reflected by a higher (landed) price, once again forcing the exporter to compete with local companies on price rather than on the basis of quality. The existence of a substitute product, at a lower price, was a situation that confronted participant M1, who reported that: 'We are producing new manufacturing equipment for cleaning materials. Because there are many other products in the market that do the same thing, but at a much cheaper price, most of the companies choose them instead of buying ours. That was a major problem to us in both the local and foreign markets, and we have been struggling to market our product as the best and most reliable'.

Another barrier faced by a majority of participants pertained to the ease of entry of new firms into the foreign markets. As a consequence, competition was very high, requiring, at times, a reduction in product quality, so that associated prices could be reduced, and sales and market share was kept at reasonable levels. For example, participant C1 stated that: 'Within the plastic industry in Saudi Arabia and the Gulf region the entry was and still considered to be easy. The big portion for the small companies starts with a very small production line with five to ten workers. This made their product very cheap due to the poor quality, and this make it hard to compete in some stages'. Similarly, participant I1 confirmed that: 'The spare parts industry in the region could be either micro or large, and that depends on you equipment and the size of your production line. Because the high availability of second hand machinery, at very good prices, has helped many micro and small businesses to start; this ease of starting and entry into the market is no doubt one of the barriers that sometimes makes it hard to sell our products in the Gulf region, due to the number of companies selling the same products'.

Additionally, most participants were faced with the problem of high competition within foreign markets. These difficulties were encountered when they targeted foreign markets producing or importing cheap products. Thus, exporting barriers, along with the influence of these barriers on risk perceptions and export-related decisions, were identified by the interviewed Saudi managers. Additionally, the results from the study reveal that more external barriers, than internal barriers, were faced in both home and host (foreign) markets. Thus, the results of these interviews shows that, as the number of the export barriers increased, higher levels of risk were perceived by the manager and that this perception influenced subsequent decisions to export. Therefore, propositions five to eight are strongly supported in this research; however, the difference between the barriers perceived within the advanced markets and the emerging markets were yet to be confirmed (see Chapter Six). Next, interviewee data associated with managers' risk perceptions are discussed.

\subsection{Australian Interviews}

The interviews further revealed barriers faced by the managers during exporting, along with the influence of these barriers on their risk perceptions associated with international expansion. The results show that external and internal barriers, in both home and host (foreign) countries, were faced by Australian SMEs managers when deciding to export their goods and these factors is greatly influenced their decision to export. The results also show that a myriad of external barriers, at both home and in the host countries, had to be faced; which influenced the decisions of the managers to export. The barriers accorded with the classifications provided in the literature review (i.e. internal-home, internal-foreign, external-home and external-foreign).

\subsubsection{Internal-Home Barriers}

All the internal home barriers were associated with management qualifications and exporting knowledge. A majority of the participants (A2, B2, C2, D2, F2, H2, I2, J2 and K2) agreed that the two most important barriers they faced pertained to the lack of qualified staff for the international market trade, as well as the lack of SMEs managers with experience in international markets. Further, being from small or medium sized firms meant that the business had staff with limited experience, and financial constraints precluded them from hiring additional employees, who possessed international marketing experience. However, two of the participants (E2 and N2) did not view these barriers as relevant to their operations. It appeared that their considerable experience, along with access to financial and human resources enabled them do export internationally, with few problems. Nevertheless, these barriers were seen as difficulties that were needed to be overcome when considering the exporting option. 
For instance, participantC2 stated that: 'We have declined in manufacturing, and managerial talent. We have declined in many aspects because we fight to compete in markets that we actually don't understand'. Also, participant $\mathrm{J} 2$ stated that: 'SMEs really suffer from a lack of qualified staff in the international markets and that influences their exporting performance'.

Another barrier identified and faced by seven participants (A2, B2, C2, D2, H2, I2, and K2) related to the limited knowledge of market intelligence for foreign markets. For example, participant B2 said that: 'Because of our short experience in exporting, we have never been good at doing market research of the foreign markets...also, we did not find any proper and reliable formal or informal channel to provide the needed information for such market research'.

\subsubsection{Internal-Foreign Barriers}

Data from the Australian interviewees revealed that a majority of the participants had never experienced any internal-foreign barriers; however, a total of four of participants (A2, C2, D2 and I2) had identified and faced (at least) one internal barrier in the foreign markets, mostly related to, the high cost of the production. These higher costs meant that their products were often at a price disadvantage compared to overseas competitors' products. As a result, their perceived inability to compete in international markets deterred them from exporting. For example, participant I2 suggested that: 'Australia, for many manufactured goods, is very expensive... because our labour market is fairly expensive than a lot of the developing markets, which makes it very difficult to export these items to markets that can get the same products cheaper somewhere else'. Similarly, participant M2 stated that: 'The cost of our products is fairly high and this places us in a position from which we find it hard to compete... with many of the cheap Asian products sold in the markets that we targeting'.

\subsubsection{External-Home Barriers}

The results also revealed that many barriers related to the companies' external environment in the home-country market. The lack of sufficient financial support from their government, to export, was identified as a major barrier by most participants (B2, F2, G2, H2, I2, J2, K2, L2, M2 and N2). This lack of support was a key concern, and made them carefully consider all options when contemplating expanding their businesses internationally. The situation was exacerbated by the need to increase production, which, in turn, led to the need for new equipment. A significant barrier related to their lack of financial resources, up-dating and upgrading their production lines (which also involved time delays), and their inability to hire more qualified staff to administer these extra activities.

Additionally, a majority of the participants faced difficulties in managing the documentation related to exporting; they all agreed that the complexity of the paperwork involved in exporting was too high in terms of time and money. Thus, participant $\mathrm{I} 2$ argued that: 'When it comes to exporting there are a lot of regulations and documentation that needs to be completed; the process cannot be done without it...this we have been experiencing with both local and foreign customs'.

All participants found that the lack of government assistance to overcome export problems constituted a major barrier that was difficult for them to overcome. They claimed that SMEs managers, in order to be successful and active exporters, needed comprehensive training on how to develop their business and expand internationally. Moreover, currently exporting SMEs identified the need for public authorities to sponsor these types of workshops. Hence, participant C2 complained: 'Why does the government sometimes give incentives that encourage and convince these companies to compete in bigger markets and, then, the same government turns around and makes it impossible for these companies to survive with no protection from the cheap imports.'

Participants L2 and M2 found that the high cost of importing raw materials together with price fluctuations of the imported raw materials were both a major barrier that deterred them from actively exporting; these barriers affected the final price of their product. As such, participant L2 commented that: 'The expensive imported raw materials, and the fluctuations of the prices, made us charge our customers more, and that impacted on us badly because our foreign competitors kept the old price'.

\subsubsection{External-Foreign Barriers}

The majority of Australian participants exported into culturally different markets (often with different customs and languages). Within the context of dissimilar external-foreign markets, they perceived a number of exporting barriers that, to a greater or lesser extent, influenced their risk perceptions and, their ultimate exporting decision. For example, frequent changes in tax and monetary policies were viewed as a barrier for three interviewees (F2, G2 and L2), especially as they exported to different regions where changes in taxation and monetary policies sometimes affected the product's price structure (and resultant competitiveness). Further, all participants identified foreign countries' internal security as an issue that could prevent them from exporting to a particular country. For example, participant G2 stated that: 'Quite a few years back we were planning to send some stuff to Venezuela, but we ended up cancelling the deal because the government had been unstable, and we thought it too risky to be involved'.

To some degree all participants reported having experienced problems in managing all the legal regulations (introduced to protect local products) in the importing countries. Consequently, these regulations affected company's exporting behaviour. For instance, participant G2 claimed that: 'The tariffs on imported goods that 
some markets charge foreign exporters, to protect the local producers, is considered as a big barrier; these charges and extra fees and tariffs force the companies to add [the costs] to the production cost...changing the final price which, at the end, gives most of the local competitors the advantage [when] competing with us on the price rather than the quality'.

In addition, another barrier identified and experienced by two participants (K2 and M2) was the high cost of transportation from Australia. Moreover, most interviewees agreed that the available of substitute from low-cost economies posed a significant problems. For instance, participant $\mathrm{K} 2$ commented that: 'The cost and the speed of the international freight is my biggest problem; it's terribly inefficient and slow and expensive, and it slows me down'. This situation is revealed by participant M2, who stated that: 'Our product is a very high quality and it's fairly expensive; that's why many companies copied our products and are selling them, even in Australia...much cheaper...some dealers in some of the markets choose them instead of buying ours, and that was a major problem for us in both local and foreign markets'.

Another barrier faced by all participants was the ease of entry of new firms into the market; this barrier increased the competition and turned, in most of the cases, into a price war. That would often impact on a manager's (and firm's) willingness to continue exporting, indeed, seek out additional exporting opportunities. For example participant argued that: 'It's easy to establish small to medium factories in most of the Asian markets due to low cost of production and equipment, and this makes us unable to compete with such companies in their markets'. Furthermore, another participant (M2) stated that: 'Companies manufacturing spare parts in the some Asian markets find it very easy to buy cheap machinery and start their business; this makes it really hard for those of us working in such markets'.

A final barrier nominated by interviewees involved the currency fluctuations for participants (L2 and M2). The problem was especially relevant as much of the raw materials they used in their products were imported from overseas markets. In particular, they often recounted difficulties associated with changes in cost resulting from international currency movements. For instance, participant G2 argued that: 'Currency fluctuation is one of the exporting barriers that we are facing and, to avoid it, we hedge a 12 month lead-time, so that we know our budget for a year and we know what we are aiming for'. Another participant (M2) reported that: 'The fluctuation in currency is a real problem we have been experiencing since the beginning. To avoid this problem we have stopped dealing with US\$ and have changed to Euros and AU\$'.

A myriad of exporting barriers, along with the influence of these barriers on risk perceptions, were identified by all of the interviewed Australian managers. The results from the study reveal that more of the nominated external barriers (in comparison to internal barriers) were faced in both home and host (foreign) countries. Thus, the results show that, as the number of the export barriers increased within all the four (previously identified) barriers categories, higher risks were perceived by the manager. Further, these perceptions influenced resultant decisions to export. Therefore, propositions five to eight received strong support in this research. However, differences between the barriers perceived within advanced markets and emerging markets are discussed in Chapter Seven. Next, the analysis of risk perception resulting from thematic analysis of the Australian interview data, is discussed.

\section{Discussion}

Exporting barriers, along with the influence of these barriers on risk perceptions, were identified by both the Saudi Arabian and Australian managers. Further, although the size of the firm did not impact upon the number of barriers to be overcome, size did influence the degree of impact of such barriers, specifically in relation to the firm's resources and capabilities to overcome them. Thus, any firm possessing more resources and capabilities usually achieved greater economies of scale, lower levels of perceived risk associated with their exporting activities, greater information/communication with the export market, product adaptation, and exogenous logistical constraints (Bonaccorsi, 1992; Katsikeas \& Morgan, 1994)

Additionally, the results from the current study reveal that more external barriers were faced in both home and host (foreign) countries than internal barriers (See Table 2 below). These barriers were renamed and reclassified by Kaleka and Katsikeas (1995), Morgan (1997), and Leonidou (1995b) into internal-domestic export barriers; internal-foreign export barriers; external-domestic export barriers; and external-foreign export barriers. Further, Hamil (1997) divided the barriers into four elements: psychological, operational, organisational, and product/market. Interestingly, the current findings show that as the number of the export barriers increase, a higher risk are perceived by managers, resulting in a lower commitment to export. Any differences among the firms appear to be based on the decision-makers' individual characteristics. Such findings affirm previous studies into the factors that influence and shape a firm's export behaviour (Katsikeas \& Morgan, 1994).

The current study also identified similar barriers to those described by Christensen, Rocha and Gertner (1987), namely: inadequate financial incentives; strong international competition; resources and capabilities of the firm; and the focus on the domestic market demand. Indeed, the Saudi Arabian and Australian interview data revealed comparable barriers to those found by Tseng and Yu (1991). Leonidou, (1995a), and Crick et al. (1998), namely: 
a lack of foreign market information; the lack of suitable or knowledgeable personnel; the inappropriateness of quality for the needs of the market; competition in export markets; a fear of imposed dumping policies; increasing tariffs; unclear trade agreements; import restrictions; and the cost of importing raw materials. These export barriers mirror those identified by Tesfom and Lutz (2006) as obstacles being faced by manufacturing firms in both developed and developing countries. Such barriers had an influence on Saudi Arabian and Australian managers' risk perceptions associated with exporting and, therefore, influenced their commitment to engage in exporting activities. Additionally, the research findings provide a new perspective on exporting barriers, and how they can act as stimuli to hinder or motivate SME exporting behaviour.

Table 2: Exporting Barriers in Saudi Arabia and Australia

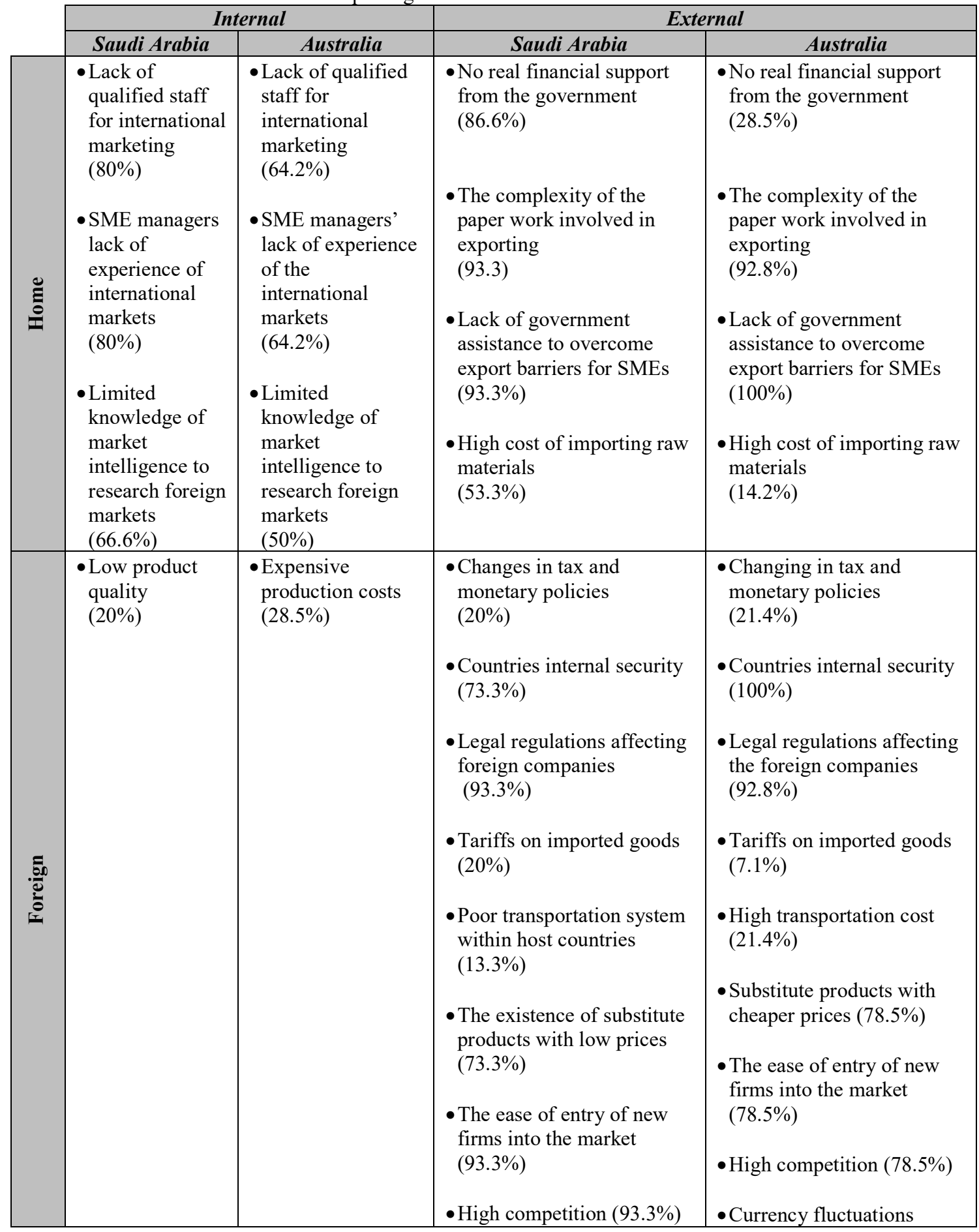




\section{Source: Developed for this research.}

The SMEs decision-makers experienced and perceived several exporting barriers, which varied from internal to external and were related to foreign to home barriers. Indeed, both Saudi Arabian and Australian managers were very experienced in their industries and perceived similar barriers during the exporting process. However, the Saudi Arabian SMEs decision-makers' perceived (and experienced)a number of different barriers, including: low product quality, and poor transportation (in some of the targeted host markets), while Australian managers perceived other barriers, including: currency fluctuations, the high cost of transportation, and the high cost of production. Further, the SMEs decision-makers all had experience with both foreign and home external barriers. However, 35.8 percent of Saudis had experienced home-internal export barriers, while 28.8 percent had faced foreign-internal export barriers. In contrast, only 20 percent of the Australian decision-makers had experienced both home and foreign-internal export barriers.

\section{Implications}

As with most research, the current study has identified a number of important and practical outcomes that can be implemented to increase the success of SME firms (especially those in Saudi Arabia) with respect to exporting. These implications include the public policy implications, which are outlined below.

The need of government policies and actions towards exporting SMEs within manufacturing appeared to be crucial and that should in a form of a direct assistance. Since there are evidence from the research results that exporting barriers are main determinants and influential of SMEs decision-makers and critical for the export decision, efforts must be made by governments to provide up-to-date information on foreign markets. The information needed should cover for example the following: economic statistics, cultural environment, government trade regulations and restrictions on imported manufacturing products, distribution channels, exchange rate policy. Which these information will help in keep firms exporting or even expands to new markets. Also, active and not active SMEs decision-makers need more assistance from the government to educate and expose managers to the international markets. That can be done through seminars, conferences and intensive training programs and workshops through government agencies is recommended to explain the real benefits of exporting to their firms by providing realistic information which can be very successful in reducing the SMEs decision-makers perception of risks associated with export related activity.

A further implication relates to the government export promotion policies which have a major impact on the SMEs competitiveness abroad. This government promotion includes, tax incentives, export and insurance, tradeaid linkage through multilateral and bilateral channels and marketing assistance. This export marketing support includes both standardised and customised foreign markets information and guidance. This can be ranged from researching specific foreign markets, individual or trade mission market visits, and trade fairs, to actual market entry.

\section{Limitations and Future Research}

The current study has been successful in achieving the research objectives and answering the research question. However, as the study investigated Saudi Arabian and Australian SMEs, with specific reference to export activities, the conclusions are not generalisable. Nevertheless, the findings can be used to provide a solid information platform for SME research within both countries, and elsewhere. Further, given that the findings are drawn from manufacturing firms, the result cannot be generalised beyond the manufacturing arena.

Additional limitations may also exist because of possible biases associated with the particular samples. For example, this study is based on existing exporting SMEs within Saudi Arabia and Australia. As a consequence, the difficulties faced by these SMEs and their exporting behaviour cannot be equated exactly with the difficulties and subsequent behaviours faced by the less experienced SMEs. In addition, during the study, every effort was made to gain a broad view of Saudi and Australian SME exporting. However, the qualitative method (convergent interviewing) used necessitated that the sample size be small. Once again this limits the generalisability of the findings, but is nevertheless consistent with expert recommendations regarding thematic saturation (Dick, 1990). These limitations are acknowledged so that the reader can put the study into context. At the same time, however, these restrictions do not reduce the efficacy of the research. Indeed, they enhance the study by highlighting the areas for future research in this important area.

For future research in this area, the current study focused on SME export firms within Saudi Arabia and Australia, and identified a range of factors that inhibit or encourage exporting within the two (advanced and emerging) countries. These findings provide a valuable background resource for future research in emerging (e.g. Turkey) and advanced (e.g. the United States of America) markets. Cross-internationalisation studies would expand and authenticate the current findings, while improving our understanding and knowledge of SME decision makers' exporting ventures, motivations and commitments. Replicating the study would determine if the findings 
hold true in other regions, and thus provide greater support for the generalisability of the findings. From a methodological point of view, future research could test the new research model using a quantitative (rather than a qualitative) survey instrument. Such an approach would increase the sample size and, once again, improve the generalisability of the findings.

Future research could also replicate and validate the findings using another experimental design, for example, longitudinal research, rather than a cross-sectional design. Longitudinal research would allow the tracking of SME decision-makers' actions, over time, and provide more extensive data regarding those factors that influence their risk perceptions associated with exporting. As a consequence, trends in decision making may be identified that assist with improving managerial and public-level policy strategies.

\section{Conclusions}

The study has explored the exporting barriers facing the Saudi Arabian and Australian SMEs engaged in exporting within manufacturing industries. This paper has identified a total of 19 exporting barriers perceived by Saudi Arabian and Australian SMEs. The study findings show that both Saudi Arabian and Australian SMEs facing more external exporting barriers, at both home and in the host markets. Additionally, the study results show that as the number of the exporting barriers facing managers' increase, the higher risk they perceived and the lower commitment to export resulted. Although outside the scope of this study, one could conjecture that regulatory/business bodies could assist in increasing management's propensity to export through providing better industry information (e.g. seminars), educational opportunities for managers and direct management assistance to influence management perceptions of risk in relation to exporting activities.

\section{References}

Aaby, N. E., \& Slater, S. F. (1989). Management influences on export performance: a review of the empirical literature 1978-88. International Marketing Review, 6(4), 7-26.

Abonyi, G (2015), ' Best Policy Practicies For Internationalization of SME' Trade and Investment for ASEAN and East Asia', in Oum, S.P. Intarakumnwed, G. Abonyi and S. Kagami (eds.), Innovation, Technology Transfers, Finance, and Internationalization of SMEs' Trade and Investment, ERIA Research Project Report FY2013, No. 14.Jakarta: ERIA, pp.37-96.

Al-Aali, A. (1995). Obstacles facing Saudi Arabian food and chemical exporters. International Journal of Commerce and Management, 5(3), 17-31.

Al-Aali, A. (1999). Obstacles perceived by Exporters in Saudi Arabia. King Saud Univ, 11(1), 19-38.

Albaum, G. (1983). Effectiveness of Government Export Assistance for U.S. Smaller-sized Manufacturers: Some Future Evidence. International Marketing Review, 1(1), 68 - 75.

Alexandrides, C. G. (1971). How the major obstacles to expansion can be overcome. In Bilkey, W. J. (1978). "An attempted integration of the literature on the export behaviour of firms." Journal of International Business Studies: 33-46.

Ali, A., \& Swiercz, P. M. (1991). Firm Size and Export Behaviour: Lessons from the Midwest. Journal of Small Business Management, 29(2).

Asiedu, E., \& Lien, D. (2004). Capital controls and foreign direct investment. World Development, 32(3), 479490.

Barkema, H. G., Bell, J. H. J., \& Pennings, J. M. (1996). Foreign entry, cultural barriers, and learning. Strategic Management Journal, 17(2).

Barker, A. T., \& Kaynak, E. (1992). An empirical investigation of the differences between initiating and continuing exporters. European Journal of Marketing, 26(3), 27-36.

Barrett, N. J., \& Wilkinson, I. F. (1985). Export stimulation: a segmentation study of the exporting problems of Australian manufacturing firms. European Journal of Marketing, 19(2), 53-72.

Bauerschmidt, A., Sullivan, D., \& Gillespie, K. (1985). Common factors underlying barriers to export: studies in the US paper industry. Journal of International Business Studies, 16(3), 111-123.

Bilkey, W. J., \& Tesar, G. (1977). The export behaviour of smaller-sized Wisconsin manufacturing firms. Journal of International Business Studies, 93-98.

Bonaccorsi, A. (1992). On the relationship between firm size and export intensity. Journal of International Business Studies, 23(4), 605-635.

Brooks, M. R., \& Rosson, P. J. (1982). A study of export behaviour of small and medium-sized manufacturing firms in three Canadian provinces. In Aaby, N. E. and S. F. Slater (1989). "Management influences on export performance: a review of the empirical literature 1978-88." International Marketing Review 6(4): 7-26, 3954.

Brouthers, K. D. (1995). The influence of international risk on entry mode strategy in the computer software industry. Management International Review, 35(1), 7-28.

Brouthers, K. D., Brouthers, L. E., \& Werner, S. (2002). Industrial sector, perceived environmental uncertainty 
and entry mode strategy. Journal of Business Research, 55(6), 495-507.

Burton, F. a. S., B. (1987). Profile Analysis of Non-exporters versus Exporters Grouped by Export Involvement. In Aaby, N. E. and S. F. Slater (1989). "Management influences on export performance: a review of the empirical literature 1978-88." International Marketing Review 6(4): 7-26.

Carson, D., Cromie, S., McGowan, P., \& Hill, J. (1995). Marketing and entrepreneurship in SMEs: an innovative approach: Prentice Hall Hemel Hempstead.

Cavusgil, S. T., \& Naor, J. (1987). Firm and management characteristics as discriminators of export marketing activity. Journal of Business Research, 15(3), 221-235.

Chen, J. (2006). Development of Chinese small and medium-sized enterprises. Journal of Small Business and Enterprise Development, 13(2), 140-147.

Cheong, W. K. \& Chong, K.W. (1988). Export Behaviour of Small Firms in Singapore. International Small Business Journal, 6(1), 34 - 41.

Christensen, C. H., Da Rocha, A., \& Gertner, R. K. (1987). An empirical investigation of the factors influencing exporting success of Brazilian firms. Journal of International Business Studies, 61-77.

Clercq, D. and Zhou, L. (2014) Entrepreneurial Strategic Posture and Performance in Foreign Markets: The Critical Role of International Learning Effort. Journal of International Marketing: June 2014, Vol. 22, No. 2, pp. 47-67.

Crick, D. (2004). UK SMEs' decision to discontinue exporting: an exploratory investigation into practices within the clothing industry. Journal of Business Venturing, 19(4), 561-587.

Crick, D., Al Obaidi, M., \& Chaudhry, S. (1998). Perceived obstacles of Saudi-Arabian exporters of non-oil products. Journal of Marketing Practice: Applied Marketing Science, 4(7), 187-199.

Dichtl, E., Koeglmayr, H. G., \& Mueller, S. (1990). International Orientation as a Precondition for Export Success. Journal of International Business Studies, 21(1).

Dick, R. (1990). Convergent interviewing: Interchange version 3. Brisbane.

D'Souza, D. E., \& McDougall, P. P. (1989). Third world joint venturing: a strategic option for the smaller firm. Entrepreneurship Theory and Practice, 14(4), 19-33.

Edmunds, S. E., \& Khoury, S. J. (1986). Exports: A necessary ingredient in the growth of small business firms Journal of Small Business Management, 24 (4), 54-65.

Ford et al. (1987). Managing Export Development between Industrialized and Developing Countries. in P.J. Rosson and S. D. Reid (eds) Managing Export Entry Expansion, New York: Praeger, 71 - 96.

Gripsrud, G. (1990). The Determinants of Export Decisions and Attitudes to a Distant Market: Norwegian Fishery Exports to Japan. Journal of International Business Studies, 21(3).

Hamill, J. (1997). The Internet and international marketing. International Marketing Review, 14(5), 300-323.

Hill, J., Nancarrow, C., \& Wright, L. T. (2002). Lifecycles and crisis points in SMEs: a case approach. Marketing Intelligence \& Planning, 20(6), 361-369.

Hofstede, G. H. (1980). Culture's Consequences: International Differences in Work-related Values: Beverly Hills: Sage Publications.

Hook, R. C., \& Czinkota, M. R. (1988). Export activities and prospects of Hawaiian firms. International Marketing Review, 5(4), 51-57.

Jaffe, E. D., \& Pasternak, H. (1994). An attitudinal model to determine the export intention of non-exporting, small manufacturers. International Marketing Review, 11(3), 17-32.

Johanson, J., \& Vahlne, J. E. (1990). The mechanism of internationalisation. International Marketing Review, 7(4), 11-24.

Kaleka, A., \& Katsikeas, C. S. (1995). Exporting problems: the relevance of export development. Journal of Marketing Management, 11, 499-499.

Karakaya, F. (2002). Barriers to entry in industrial markets. Journal of Business \& Industrial Marketing, 17(5), 379-388.

Katsikeas, C. S., \& Morgan, R. E. (1994). Differences in perceptions of exporting problems based on firm size and export market experience. European Journal of Marketing, 28(5), 17-35.

Kaynak, E., Ghauri, P. N., \& Olofsson-Bredenlow, T. (1987). Export behaviour of small Swedish firms. Journal of Small Business Management, 25(2), 26-26.

Kaynak, E. (1992). A Cross Regional Comparison of Export Performance of Firms in Two Canadian Regions. Management International Review, 32(2), 163 - 180.

Kaynak, E., \& Kothari, V. (1984). Export behaviour of small and medium-sized manufacturers: Some policy guidelines for international marketers. In Aaby, N. E. and S. F. Slater (Eds). Management influences on export performance: a review of the empirical literature 1978-88. International Marketing Review 6(4): 7-26.

Kedia, B. L., \& Chhokar, J. (1986). Factors inhibiting export performance of firms: an empirical investigation. Management International Review, 26(4), 33-43.

Keng, K. A., \& Jiuan, T. S. (1989). Differences between small and medium sized exporting and non-exporting 
firms: nature or nurture. International Marketing Review, 6(4), 27-40.

Korth, C. M. (1991). Managerial barriers to US exports. Business Horizons, 34(2), 18-26.

Lado, N., Martínez-Ros, E., \& Valenzuela, A. (2001). Explaining export regional involvement through marketing strategy: the case of Spanish companies exporting to Latin America. Working paper, Business Economics, , Series 09, 1-26.

Leonidou, L. C. (1995). Export stimulation: a non-exporter's perspective. European Journal of Marketing, 29(8), 17-36.

Leonidou, L. C. (1995a). Export barriers: non-exporters' perceptions. International Marketing Review, 12(1), 425.

Leonidou, L. C. (2003). Overcoming the limits of exporting research using the relational paradigm. International Marketing Review, 20(2), 129-141.

Leonidou, L. C. (2004). An Analysis of the Barriers Hindering Small Business Export Development. Journal of Small Business Management, 42(3), 279-303.

Lim, J. S., Sharkey, T. W., \& Kim, K. I. (1991). An empirical test of an export adoption model. Management International Review, 31(1), 51-62.

Lind, P., Sepúlveda, E., \& Nuñez, J. (2000). On the applicability of a computer model for business performance analysis in SMEs: a case study from Chile. Information Technology for Development, 9(1), 33-44.

Madsen, T. K. (1989). Successful export marketing management: some empirical evidence. International Marketing Review, 6(4), 41-57.

Moini, A. H. (1998). Small firms exporting: how effective are government export assistance programs? Journal of Small Business Management, 36(1).

Morgan, D. L. (1998). Practical strategies for combining qualitative and quantitative methods: applications to health research. Qualitative health research, 8(3), 362.

Neupert, K. E., Baughn, C. C., \& Dao, T. T. L. (2006). SME exporting challenges in transitional and developed economies. Journal of Small Business and Enterprise Development, 13(4), 535-545.

Ojala, A., \& Tyrvainen, P. (2007). Market entry decisions of US small and medium-sized software firms. Management Decision, 46(2), 187-200.

Pavord, W. C., \& Bogart, R. G. (1975). The dynamics of the decision to export. Akron Business and Economic Review, 6(1), 6-11.

Rabino, S. (1980). An examination of barriers to exporting encountered by small manufacturing companies. In Leonidou, L. C. (Eds). An Analysis of the Barriers Hindering Small Business Export Development. Journal of Small Business Management 42(3): 279-303.

Reid, S. D. (1981). The decision-maker and export entry and expansion. Journal of International Business Studies, 101-112.

Saudi Ministry of Commerce and Industry (2008). Strategic Positioning and Industrial Development Vision For the Kingdom of Saudi Arabia. Retrieved on September 25, 2008 from, http://www.commerce.gov.sa/english/moci.aspx?PageObjectId=806

Samiee, S., \& Walters, P. G. P. (1990). Influence of firm size on export planning and performance. Journal of Business Research, 20(3), 235-248.

Spence, M. (2003). International strategy formation in small Canadian high-technology companies-a case study approach. Journal of International Entrepreneurship, 1(3), 277-296.

Sullivan, D., \& Bauerschmidt, A. (1990). Incremental internationalization: a test of Johanson and Vahlne's thesis. Management International Review, 30(1), 19-30.

Tesar, G., \& Tarleton, J. S. (1982). Comparison of Wisconsin and Virginia small and medium-sized exporters: aggressive and passive exporters. In Aaby, N. E. and S. F. Slater (1989). "Management influences on export performance: a review of the empirical literature 1978-88." International Marketing Review 6(4): 7-26, 85112.

Vosikis, G. S., \& Palmour, K. (1980). A Strategic Disadvantage Profile of the Stages of the Exporting Process: The Experience of Small Business Exporters in Georgia. In Morgan, R. E. (Eds). Export stimuli and export barriers: evidence from empirical research studies. European Business Review 97(2): 68-79.

Weinrauch, J. D., \& Rao, C. P. (1974). The export marketing mix: an examination of company experiences and perceptions. Journal of Business Research, 2(4), 447-452.

Westhead, P., Wright, M., \& Ucbasaran, D. (2001). The internationalization of new and small firms A resourcebased view. Journal of Business Venturing, 16(4), 333-358.

Yang, Y. S., Leone, R. P., \& Alden, D. L. (1992). A market expansion ability approach to identify potential exporters. The Journal of Marketing, 56(1), 84-96.

Yaprak, A. (1985). A empirical study of the differences between small exporting and non-exporting US firms. International Marketing Review, 2(2), 72-83. 